\title{
Approach to assess infrared thermal imaging of almond trees under water-stress conditions
}

Iván García-Tejero, Víctor Hugo Durán-Zuazo, Javier ArRiagA, Almudena Hernández, Luisa Maria Vélez, José Luis MURIEL-FERNÁNDEZ

Inst. Andal. Investig. Form. Agrar. Pesq. Prod. Ecol. (IFAPA), Cent. "Las TorresTomejil", Ctra. Sevilla-Cazalla, Km. 12,2, Alcalá del Río (Sevilla), Spain, victorh.duran@ juntadeandalucia.es
* Correspondence and reprints

Received 13 December 2011 Accepted 9 February 2012

Fruits, 2012, vol. 67, p. 463-474 (C) 2012 Cirad/EDP Sciences All rights reserved DOI: 10.1051/fruits/2012040 Www.fruits-journal.org

RESUMEN ESPAÑOL, p. 474

\section{Approach to assess infrared thermal imaging of almond trees under water-stress conditions.}

Abstract - Introduction. Optimising agricultural water use implies the combination of physiological, technological and engineering techniques, especially those for continuously monitoring the water status of plants subjected to deficit irrigation. A methodology to estimate water stress of young almond trees from thermal images was developed based on assessing the physiological status of almond crops under limited water-supply conditions. Materials and methods. Two irrigation treatments were tested during the maximum evapotranspirative demand period (214th to the 243rd day of the year) in an experimental almond [Prunus dulcis (Mill) D.A. Webb, cv. Guara] orchard: a low-frequency deficit irrigation (LFDI) treatment, irrigated according to the plant-water status, and a fully irrigated treatment $\left(\mathrm{C}_{100}\right)$ at $100 \%$ of crop evapotranspiration. Daily canopy temperature at midday $\left(\mathrm{T}_{\mathrm{C}}\right)$ was measured with an infrared camera, together with standard measurements of stem-water potential $\left(\Psi_{\text {Stem }}\right)$ and stomatal conductance $\left(\mathrm{g}_{\mathrm{S}}\right)$. The time course of these parameters and their relationships were analysed. Results and discussion. The time course of the parameters studied showed highly significant correlations among the differentials of canopy-air temperature $(\Delta \mathrm{T}), \Psi_{\text {Stem }}$ and $g_{\mathrm{S}}$. The methodological protocol for analysing thermal images allowed a time saving in processing information and additionally offered the possibility of estimating the $\Psi_{\text {Stem }}$ and $g_{S}$ values. Conclusion. Our results confirm that infrared thermography is a suitable technique for assessing the crop-water status and can be used as an important step towards automated plant-water stress management in almond orchards.

Spain / Prunus dulcis / canopy / temperature / infrared thermography / water requirements / soil water deficit

Approche pour évaluer l'imagerie thermique infrarouge d'amandiers en conditions de stress hydrique.

Résumé - Introduction. Optimiser l'utilisation de l'eau en agriculture implique de combiner des techniques physiologiques, technologiques et d'ingénierie, en particulier celles qui permettent de surveiller en permanence l'état hydrique de plantes soumises à un déficit d'irrigation. Une méthodologie pour estimer le stress hydrique de jeunes amandiers à partir d'images thermiques a été développée sur la base de l'évaluation de l'état physiologique d'arbres placés en conditions d'alimentation en eau limitée. Matériel et méthodes. Deux traitements d'irrigation ont été testés au cours de la période de demande evapotranspirative maximale (214e au 243e jour de l'année) dans un dispositif expérimental en verger d'amandiers [Prunus dulcis (Mill.) D.A. Webb., cv. Guara] : un traitement avec une irrigation déficitaire à basse fréquence (LFDI), irrigué en fonction du statut hydrique des plants, et un traitement irrigué à $100 \%$ de l'évapotranspiration des cultures $\left(\mathrm{C}_{100}\right)$. La température quotidienne du couvert à midi $\left(\mathrm{T}_{\mathrm{C}}\right)$ a été mesurée à l'aide d'une caméra infrarouge, ainsi que des mesures standards du potentiel hydrique de la tige $\left(\Psi_{\text {Stem }}\right)$ et de la conductance stomatique $\left(\mathrm{g}_{\mathrm{s}}\right.$ ). L'évolution dans le temps de ces paramètres et leurs relations ont été analysées. Résultats et discussion. L'évolution dans le temps des paramètres mesurés et leurs relations ont mis en évidence des corrélations hautement significatives entre la différence de température canopie-air $(\Delta \mathrm{T})$, et les paramètres $\Psi$ Stem, et $\mathrm{g}_{\mathrm{S}}$. Le protocole méthodologique pour l'analyse des images thermiques a permis un gain de temps pour le traitement de l'information et a offert en plus la possibilité d'estimer les valeurs de $\Psi$ Stem et de $g_{S}$. Conclusion. Nos résultats confirment que la thermographie infrarouge est une technique appropriée pour l'évaluation de l'état hydrique des cultures et qu'elle peut être utilisée comme une technique adaptée à la gestion automatisée du stress hydrique des plants en vergers d'amandiers.

Espagne / Prunus dulcis / couvert / température / thermographie infrarouge / besoin en eau / déficit hydrique du sol 


\section{Introduction}

Almond [Prunus dulcis (Mill) D.A. Webb], with more than $650,000 \mathrm{ha}$, is after the olive (Olea europaea L.) and the grape (Vitis vinifera L.) the third woody crop in growing area in Spain ${ }^{1}$. Although traditionally considered a highly drought-tolerant crop, under non-limiting conditions, almond significantly improves crop yield, generating high economic profits, with yields up to 10 times higher than under rainfed conditions [1-4], and with a great adaptability to water shortage [5, 6]. In many arid and semiarid areas, irrigation availability is one of the most limiting factors for increasing almond yield, and therefore deficit irrigation is often a viable alternative to maintain crop yield at levels similar to those of non-limiting water conditions, and hence, improving over rainfed situations $[7,8]$.

However, under deficit irrigation, a continuous control of tree-water status is crucial [9]. The stem-water potential $\left(\Psi_{\text {Stem }}\right)$ and stomatal conductance $\left(g_{S}\right)$ provide reference measurements for assessing the plantwater status, and hence have been used for irrigation scheduling in many crops [10-12]. According to García-Tejero et al., such measurements require time and adequate field staff [13]. Thus, the direct examination of some plant physiological factors is necessary to optimise irrigation, especially in arid and semi-arid areas such as SW Spain, where irrigation is crucial for enhancing crop production.

Therefore, alternative indicators related to the crop-water status are essential for irrigation timing and automation. Canopy temperature $\left(\mathrm{T}_{\mathrm{C}}\right)$ indicates crop-water stress, this being highly related to the daily crop transpiration. In crop transpiration, latent heat is given off as evaporation, decreasing the canopy temperature $\left(\mathrm{T}_{\mathrm{C}}\right)$ with respect to air temperature $\left(\mathrm{T}_{\text {air }}\right)$ [14]. When the crop is subjected to water stress the transpiration level declines, increasing the $\mathrm{T}_{\mathrm{C}}$ with regard

\footnotetext{
${ }^{1}$ FAOSTAT, Food and agriculture organization of the United Nations, available at http://faostat. fao.org/ [September 2011].
}

to $\mathrm{T}_{\text {air }}$, which is linked with lower crop evapotranspiration and stomatal conductance [15, 16].

New approaches for assessing the plantwater status through remote or non-invasive methods have been proposed using infrared thermometry. Canopy temperature has been shown to be associated with other physiological parameters such as stomatal conductance, $\Psi_{\text {Stem }}$ or maximum daily shrinkage, among others [17-19]. These measurements are taken mainly through infrared cameras, which capture thermal images of crops, in a similar way to satellite imagery, but with the advantage that these can be taken at any time, without the limitations to the treatment and analysis of images remotely captured by satellite [20].

Despite the advantages associated with the use of such tools, some limitations result from the procedure of capturing and processing data, requiring in many cases the use of complex software and thus reducing the operational ease and affordability of such techniques. Hand-operated cameras offer images of individual plants or portions thereof, but with the disadvantage that, during the photographing process, different elements (soil, shady areas, sky or portions of adjacent plants) can be reflected, requiring subsequent time-consuming image processing. This difficulty is especially marked in young woody crops, with discontinuous canopies [14].

Many authors have described different methods to overcome such limitations, although all approaches require different image processing, either through editing software or pixel classification, or through relatively laborious statistical analysis [2124].

The aim of our study was to develop an alternative methodology for assessing the canopy temperature $\left(\mathrm{T}_{\mathrm{C}}\right)$ from thermography images without pretreating images, and avoiding interference and masking by other materials. This is accomplished with standard physiological parameters for assessing water stress in almond trees under waterstress conditions. 


\section{Materials and methods}

\subsection{Experimental conditions}

The trial was conducted during 2011, in an experimental orchard of almond [Prunus dulcis (Mill.) D.A. Webb., cv. 'Guara', grafted onto GF677], located in Alcalá del Río, some $18 \mathrm{~km}$ to the north of Seville (37³0' N, 558' W) (SW Spain). The young almond orchard was planted in 2010, spaced at $7 \mathrm{~m} \times 6 \mathrm{~m}$, and drip-irrigated with a pipe line with two pressure-compensated emitters per tree, with a flow rate of $2 \mathrm{~L} \cdot \mathrm{h}^{-1}$.

The soil is silty loam, typical Fluvisol [25], with $2.5 \mathrm{~m}$ depth, fertile, and low organicmatter content $\left(<15.0 \mathrm{~g} \cdot \mathrm{kg}^{-1}\right)$. Tree roots were located predominantly in the uppermost $0.45 \mathrm{~m}$ of the profile, corresponding to the intended wetting depth. Soil-water-content values at field capacity $(-0.3 \mathrm{MPa})$ and wilting point $(-1.5 \mathrm{MPa})$ were 0.39 and 0.13 , respectively, with an available soil-water capacity averaging $0.26 \mathrm{~m}^{3} \cdot \mathrm{m}^{-3}$.

The climate in the area is attenuated mesoMediterranean [26], with an annual average precipitation and reference evapotranspiration of $(534$ and 1,400$) \mathrm{mm} \cdot \mathrm{year}^{-1}$, respectively.

\subsection{Experimental set-up and irrigation treatments}

Two irrigation treatments were applied under both experimental conditions: (a) control treatment $\left(\mathrm{C}_{100}\right)$, irrigated at $100 \%$ of crop evapotranspiration $\left(\mathrm{ET}_{\mathrm{C}}\right)$, and (b) lowfrequency deficit irrigation (LFDI), irrigated according to the plant-water status. So, in this treatment, different irrigation-restriction cycles were established according to the canopy temperature $\left(\mathrm{T}_{\mathrm{C}}\right)$ at midday. When significant differences $(p<0.05)$ were detected between control $\left(\mathrm{C}_{100}\right)$ and LFDI, stressed trees were irrigated with the same amount of water and frequency as $\mathrm{C}_{100}$. Additionally, when $T_{C}$ values at midday in this treatment were similar to $\mathrm{T}_{C}$ values for the control treatment, irrigation was withheld until the $\mathrm{T}_{C}$ values were again significantly different.
Regarding the low-frequency deficit irrigation (LFDI) treatment, it was subjected to irrigation restrictions during the maximum evapotranspirative demand period, from the 214 th to the 243 rd day of the year (DOY). That is, this treatment received no irrigation in relation to the control treatment, which was fully irrigated, according to the crop evapotranspiration demand (ETc), using a reference crop coefficient $(K c)$ and a reduction coefficient $(K r)$ of 0.6 and 0.3 , respectively [27]. Irrigation treatments were displayed in a randomised-block design with three replicate plots per treatment, and monitoring six trees per replicate.

\subsection{Plant measurements}

During the experimental period (214th to 243 rd day of the year), canopy temperature readings were taken with a thermalimaging thermographic camera (ThermaCamTM FLIR-SC660 System, Inc., UK). This camera supplies infrared or visible spectrum images of high quality, allowing accurate temperature measurement, with an infrared pixel resolution of $640 \times 480$ and a spectral range of $7.5 \mu \mathrm{m}$ to $13.5 \mu^{2}$, with an established emissivity for crop vegetation of 0.98 [28]. With the same periodicity, $\Psi_{\text {Stem }}$ was measured in two leaves per sampling tree, between 11:00 and 12:00 h solar time, and every $24-48$ hours. $\Psi_{\text {Stem }}$ was monitored in shaded mature leaves close to the north quadrant and near the trunk, using a Scholander pressure chamber [29] (Soil Moisture Equipment Corporation, Sta. Barbara, CA, USA). At the same time, the stomatal conductance $g_{S}$ was measured in two sunny leaves per tree, using a diffusion porometer AP-4 (Delta-T Devices, Cambridge, UK).

\subsection{Infrared image acquisition, analysis, and calculations}

The images were taken $3 \mathrm{~m}$ from the sunny side of the canopy, with a wet cooled cloth

\footnotetext{
${ }^{2}$ Flir Systems Thermography, Flir P-Series, infrared perfection, available at www.support.flir.com/../ A365-P\%20series\%20brochure\%20def.pdf/ [September 2011].
} 


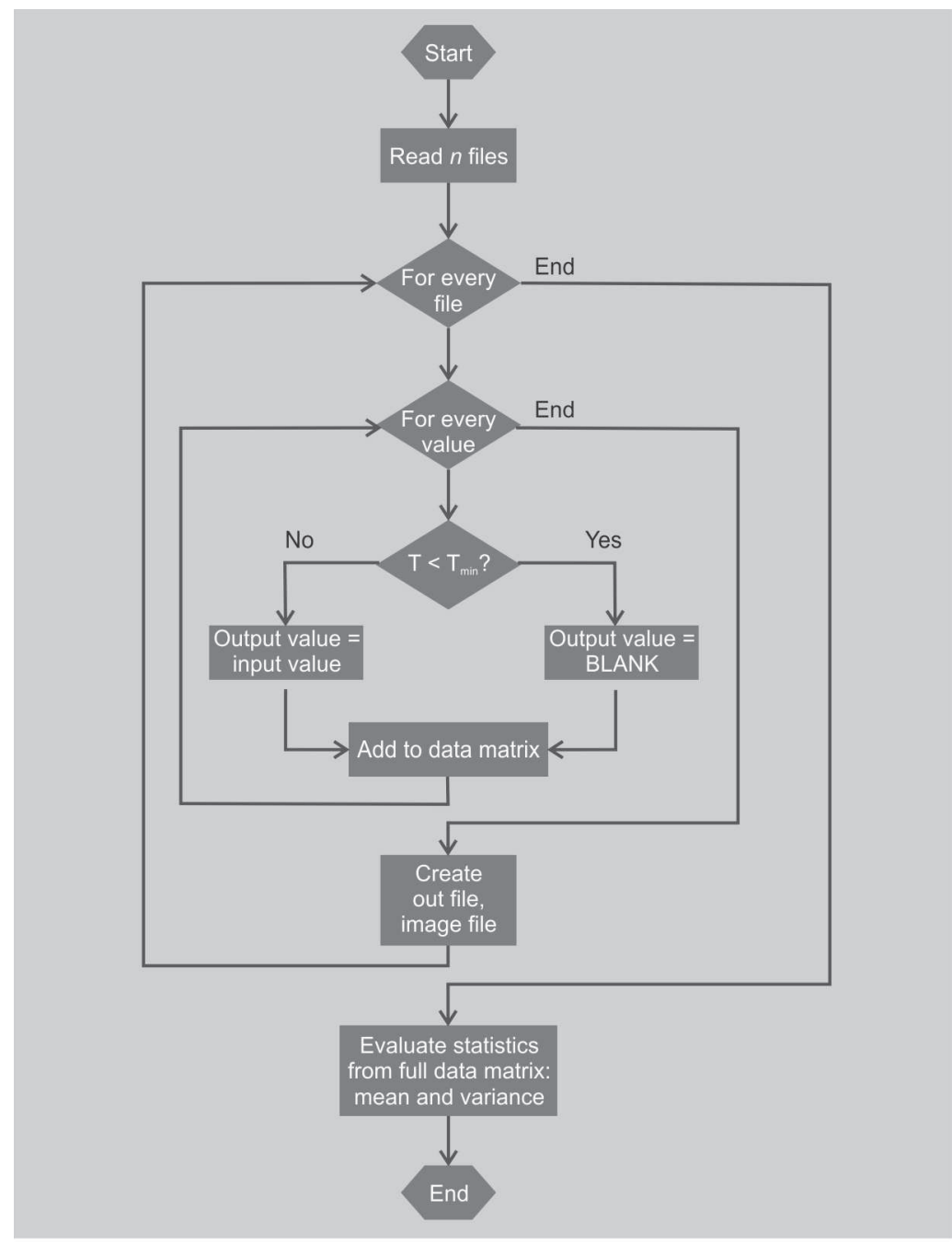

Figure 1. Flowchart for image analysis process. (screen) just behind the tree canopy, in order to simplify the isolation of the canopy surface through image processing based on temperature differences. The raw thermal images were obtained by means of ThermaCam Explorer software (FLIR QuickReport) as a 'TIFF' image. The images were then processed, using the FLIR software for exporting these images from TIFF to a 'CSV' file (comma-separated values). The new file generated contained a large number of cells, with temperature values in each tile per pixel. The CSV file could be uploaded with an 'XLS' datasheet, which was limited to a maximum of 256 columns, and, in most cases, images were considerably larger. A way to solve this difficulty is to select and export different image sections; in our case, three consecutive areas per image were required.

The flow chart for image analysis process from selected images was synthesised (figure 1). Thus, since every section was saved in different datasheet files, it was necessary to make a selection by removing for each 'CSV' file the temperature values below a certain threshold (temperature values pertain to wet cooled cloth), and thus leaving the pixels from the tree canopy with its temperature values. Determining the mean and variance for every file is quite easy, but, in order to determine the real mean (and especially the variance) of the full image, more complex procedures are required.

To automate this procedure, a $\mathrm{C}$ program $[30,31]$ was created. This program asks the operator for the desired file names and temperature limit, erasing the data below the limit, and saves the results in plain text format, calculating the average $\left(\mathrm{T}_{\mathrm{C}},{ }^{\circ} \mathrm{C}\right)$ and variance for the full set of files. Finally, it creates a DIB (Device-Independent Bitmap) ${ }^{3}$ monochrome file to show the 'real image' of the tree canopy. The bitmap (BMP) file was chosen because it can be easily implemented without specific software libraries. The program runs with up to three image sections and it has been programmed using cross-platform standards; therefore, it can be used in any system with a console interface. Additionally, the minimum $\left(\mathrm{T}_{\min },{ }^{\circ} \mathrm{C}\right)$ and maximum $\left(\mathrm{T}_{\max },{ }^{\circ} \mathrm{C}\right)$ temperatures can be determined for each canopy monitored, using the same program.

\subsection{Data analysis}

An exploratory and descriptive analysis was done of $\Psi_{\text {Stem }}$, stomatal conductance and canopy temperature, followed by $t$-test analysis using the SPSS 15.0 statistical package (SPSS, Chicago, IL, USA). Additionally, $\Psi_{\text {Stem }}$, stomatal conductance and

\footnotetext{
${ }^{3}$ MSDN, DIBs and their uses, available at http:// msdn.microsoft.com/en-us/library/ms969901. aspx [September 2011].
} 


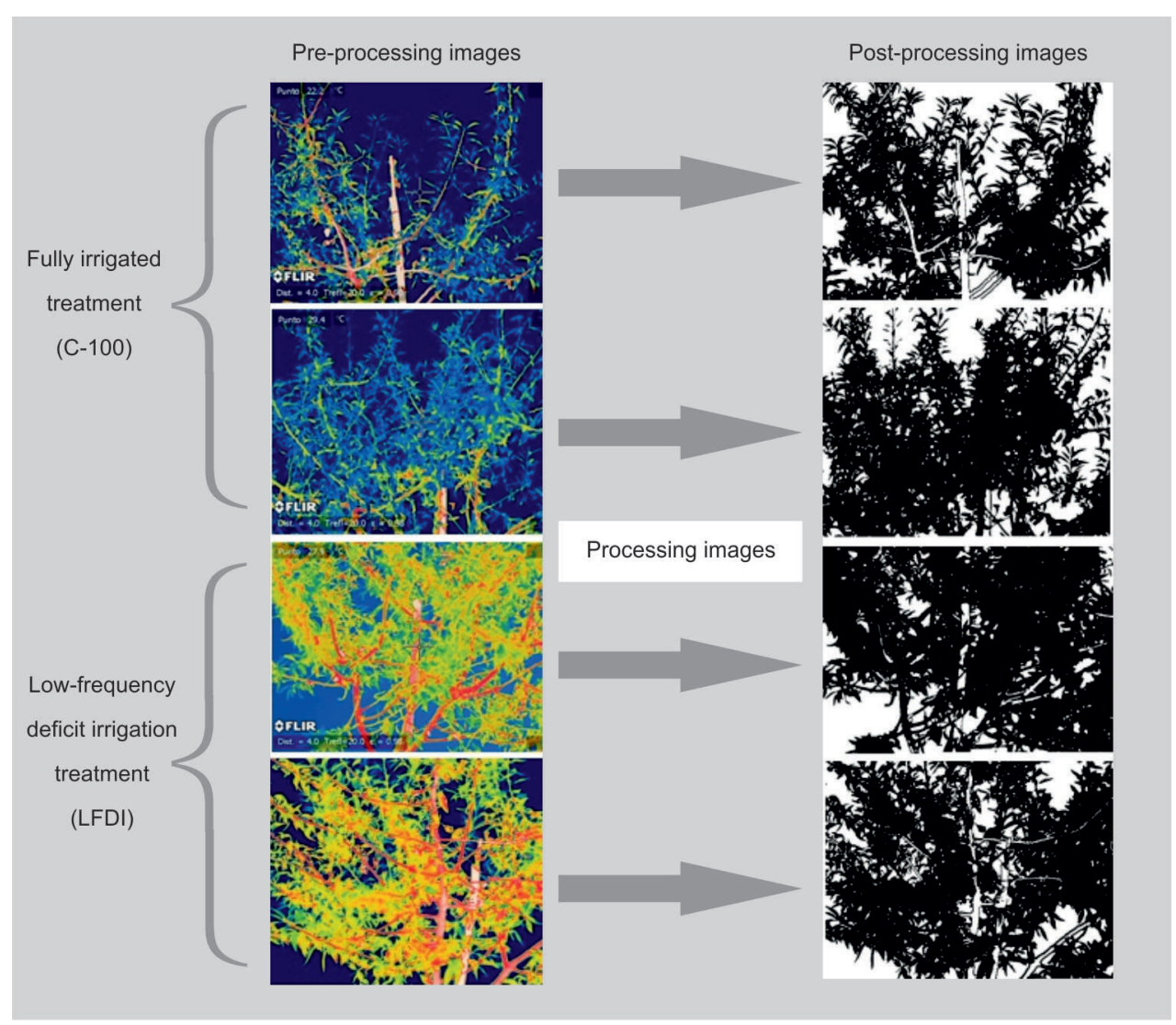

temperature variation $(\Delta \mathrm{T})$ were correlated, estimating the feasibility of canopy temperature readings as a continuous plant-based water-stress indicator, and establishing the physiological threshold values. Finally, a validation was conducted to assess the performance of these relationships, estimating the determination coefficient $\left(r^{2}\right)$ and root mean square error (RMSE).

\section{Results and discussion}

\subsection{Processing images}

In each thermal image the threshold was determined for the maximum and minimum temperatures that allowed the pre-treatment of data (figure 2). A post-treatment consisted of obtaining for each image only the pixels that belonged solely to the canopy area, avoiding the masking pixels that belonged to other tree sections as well as other materials present in the field.

The result was a CSV file, after the conversion data, which indicated the cells with temperature values outside of the set range, keeping the values that corresponded strictly to the tree canopy studied. Afterwards, the $\mathrm{C}$ program created a BMP file, in which each cell with a canopy-temperature value was converted into a 'black pixel', with 'white' representing the pixels corresponding to the cells that had been screened. The code box for the Basic programming language that describes its procedure is given (figure 3).

The main advantage of this protocol is the time saved in processing thermal images. The $C$ program allowed maximum and minimum threshold temperature values to be defined by selecting only the pixels that belonged to the canopy area, avoiding even those corresponding to values of the trunk or branches.
Figure 2.

Thermal image processing of almond trees submitted to two treatments: fully irrigated treatment and low-frequency deficit irrigation treatment during the maximum evapotranspirative demand period. 
Figure 3.

Code box in programming language for conversion of data regarding parameters measured on almond trees.

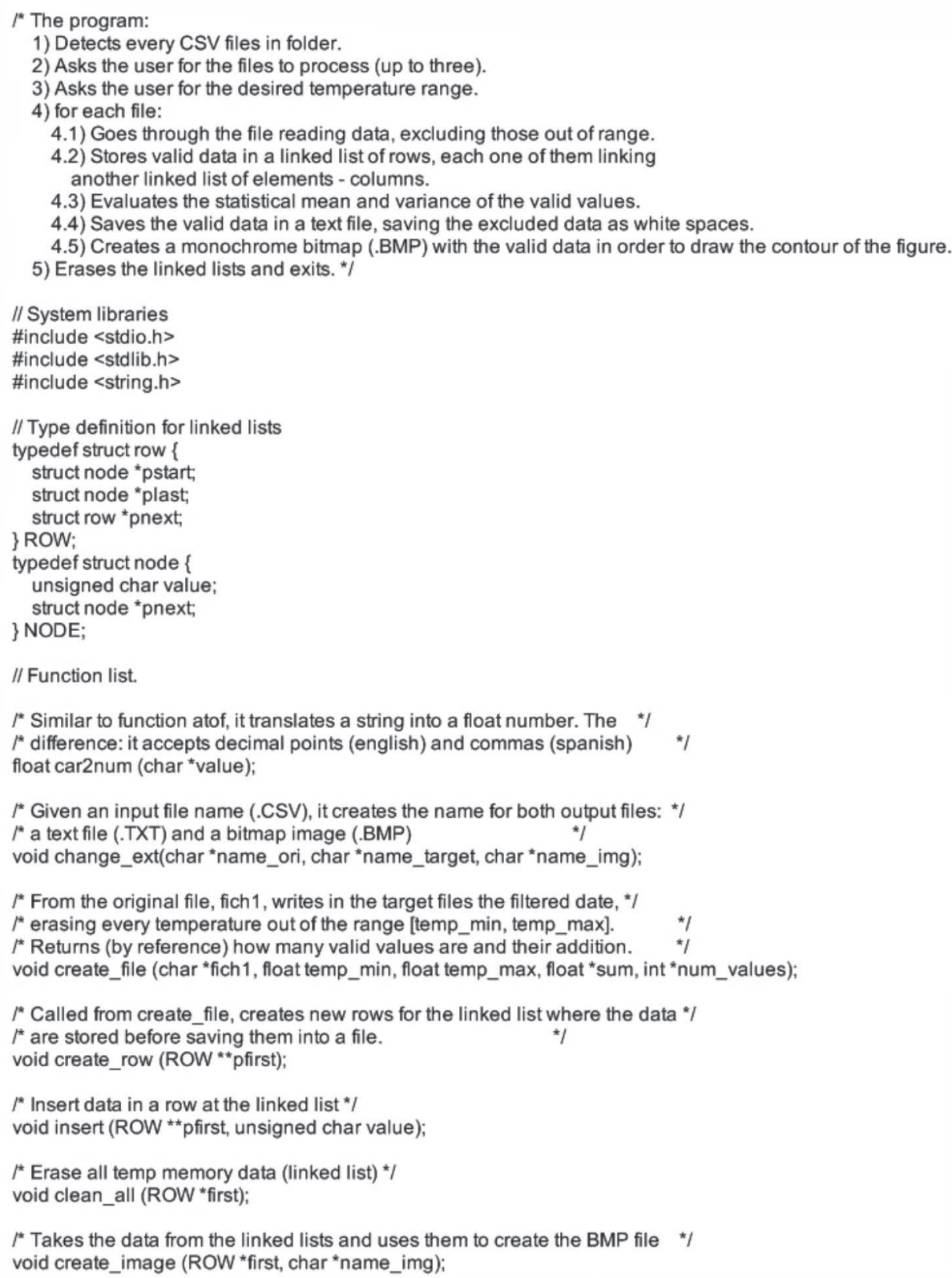

\subsection{Plant physiological dynamics}

The time course of $\Psi_{\text {Stem }}$, stomatal conductance $g_{S}$ and canopy temperature $\mathrm{T}_{\mathrm{C}}$ for the control and LFDI treatment was registered from the 214th to the $243 \mathrm{rd}$ day of the year (table I). During the experimental period, accumulative ETc was close to $31 \mathrm{~mm}$. That is, during this period, control trees received a total of $27.7 \mathrm{~mm}$ of water, this being approximately $90 \%$ of ETc, whereas LFDI received no irrigation. These irrigation dynamics in each treatment promoted significant effects on the physiological variables.

The $\Psi_{\text {Stem }}$ in control trees ranged between $-0.91 \mathrm{MPa}$ and $-1.75 \mathrm{MPa}$, these values being in line with those reported by other authors under non-limiting water 
Table I.

Timing evolution of stem-water potential $\left(\Psi_{\text {stem }}\right)$, stomatal conductance $\left(g_{\mathrm{S}}\right)$ and canopy temperature $\left(T_{\mathrm{C}}\right)$ for almond trees during a monitoring period.

\begin{tabular}{|c|c|c|c|c|c|c|c|}
\hline \multirow[t]{2}{*}{$\begin{array}{l}\text { Day of the } \\
\text { year }\end{array}$} & \multirow{2}{*}{$\begin{array}{c}\text { Air } \\
\text { temperature } \\
\left({ }^{\circ} \mathrm{C}\right)\end{array}$} & \multicolumn{3}{|c|}{$\begin{array}{l}\text { Control treatment fully irrigated at } 100 \% \\
\qquad\left(C_{100)}\right.\end{array}$} & \multicolumn{3}{|c|}{$\begin{array}{l}\text { Low-frequency deficit irrigation } \\
\text { (LFDI) }\end{array}$} \\
\hline & & $\begin{array}{c}\text { Stem-water } \\
\text { potential } \\
\Psi_{\text {stem }} \\
\text { (MPa) }\end{array}$ & $\begin{array}{c}\text { Stomatal } \\
\text { conductance } \\
\mathrm{g}_{\mathrm{S}} \\
\left(\mathrm{mmol} \cdot \mathrm{m}^{-2} \cdot \mathrm{s}^{-1}\right)\end{array}$ & $\begin{array}{c}\text { Canopy } \\
\text { temperature } \\
\mathrm{T}_{\mathrm{C}} \\
\left({ }^{\circ} \mathrm{C}\right)\end{array}$ & $\begin{array}{c}\text { Stem-water } \\
\text { potential } \\
\Psi_{\text {stem }} \\
\text { (MPa) }\end{array}$ & $\begin{array}{c}\text { Stomatal } \\
\text { conductance } \\
\mathrm{gs}_{\mathrm{S}} \\
\left(\mathrm{mmol} \cdot \mathrm{m}^{-2} \cdot \mathrm{s}^{-1}\right)\end{array}$ & $\begin{array}{c}\text { Canopy } \\
\text { temperature } \\
\mathrm{T}_{\mathrm{C}} \\
\left({ }^{\circ} \mathrm{C}\right)\end{array}$ \\
\hline 214 & 27.2 & $-1.4 \pm 0.1$ & $95.1 \pm 18.8$ & $26.6 \pm 0.7$ & $-1.1 \pm 0.2$ & $108.4 \pm 27.5$ & $27.2 \pm 0.4$ \\
\hline 216 & 33.0 & $-1.4 \pm 0.1$ & $356.0 \pm 35.6$ & $29.6 \pm 0.4$ & $-1.9 \pm 0.2^{*}$ & $423.0 \pm 58.4$ & $29.2 \pm 0.9$ \\
\hline 217 & 32.6 & $-1.3 \pm 0.1$ & $290.0 \pm 68.3$ & $30.3 \pm 0.5$ & $-1.7 \pm 0.2^{*}$ & $253.2 \pm 32.9$ & $30.9 \pm 0.5$ \\
\hline 220 & 35.0 & $-1.3 \pm 0.2$ & $394.2 \pm 57.6$ & $30.9 \pm 0.5$ & $-1.7 \pm 0.1^{*}$ & $274.4 \pm 65.6$ & $31.0 \pm 0.5$ \\
\hline 222 & 33.6 & $-1.7 \pm 0.2$ & $336.9 \pm 76.8$ & $31.8 \pm 0.3$ & $-2.1 \pm 0.1^{*}$ & $262.5 \pm 39.5$ & $32.0 \pm 0.4$ \\
\hline 224 & 30.8 & $-1.2 \pm 0.2$ & $540.8 \pm 43.2$ & $29.4 \pm 0.4$ & $-1.7 \pm 0.2^{*}$ & $326.0 \pm 63.3^{\star}$ & $29.3 \pm 0.2$ \\
\hline 228 & 34.0 & $-1.5 \pm 0.1$ & $482.8 \pm 66.3$ & $32.4 \pm 0.4$ & $-1.8 \pm 0.3^{*}$ & $348.2 \pm 95.7$ & $32.4 \pm 0.7$ \\
\hline 230 & 30.6 & $-1.5 \pm 0.2$ & $494.7 \pm 85.5$ & $29.6 \pm 0.5$ & $-1.9 \pm 0.3^{*}$ & $387.8 \pm 97.0$ & $29.5 \pm 0.5$ \\
\hline 234 & 27.8 & $-0.9 \pm 0.1$ & $523.3 \pm 43.7$ & $27.1 \pm 0.4$ & $-1.5 \pm 0.2^{*}$ & $404.5 \pm 75.9^{*}$ & $27.8 \pm 0.3^{*}$ \\
\hline 237 & 30.4 & $-1.3 \pm 0.3$ & $383.8 \pm 53.5$ & $28.5 \pm 0.4$ & $-1.9 \pm 0.2^{*}$ & $272.0 \pm 82.6^{\star}$ & $28.6 \pm 0.6$ \\
\hline 243 & 25.7 & $-1.3 \pm 0.1$ & $358.3 \pm 29.6$ & $27.1 \pm 0.9$ & $-1.7 \pm 0.2^{*}$ & $228.5 \pm 43.5^{\star}$ & $27.8 \pm 0.9^{*}$ \\
\hline
\end{tabular}

availability [32-34], whereas LFDI ranged between $-1.18 \mathrm{MPa}$ and $-2.18 \mathrm{MPa}$. Thus, throughout the monitoring period, significant differences between treatments were found.

According to the time course of stomatal conductance, these differences were not as pronounced as in the $\Psi_{\text {Stem }}$, ranging from (95 to 540$) \mathrm{mmol} \cdot \mathrm{m}^{-2} \cdot \mathrm{s}^{-1}$ in control trees and from (108 to 423 ) $\mathrm{mmol} \cdot \mathrm{m}^{-2} \cdot \mathrm{s}^{-1}$ in LFDI, these values being in line with those reported by Nortes [34] in a long-term experiment of regulated deficit irrigation in almond trees. The limited effect of water deficit in this parameter was reflected in the absence of significant differences between treatments for most of the sampling period, which were patent only in the final days (DOY: 234-243).

Due to the strong relationship between $\mathrm{T}_{\mathrm{C}}$ and crop-transpiration levels, the $\mathrm{T}_{\mathrm{C}}$ showed a similar trend of stomatal conductance, hence the significant differences being shown at the end of the monitoring period.
The $\Psi_{\text {Stem }}$ and stomatal conductance records in LFDI were according to those reported by other authors such as GomesLaranjo et al., who established $\Psi_{\text {Stem }}$ ranges of $-2.3 \mathrm{MPa}$ to $-2.9 \mathrm{MPa}$ in non-irrigated almonds [35]. As stated by Chaves et al., stomatal aperture is governed by several weather and soil-water conditions [36].

According to the sensitivity of the different water-stress indicators, this is related to the degree of change in water status that can be found statistically. Therefore, the sensitivity of a water-stress indicator is expected to increase with the level of response of the sensor to changes in water status, and to decrease with greater variability between sensors/readings [37]. In line with these results, water stress was detected earlier with $\Psi_{\text {Stem }}$ than with stomatal conductance and canopy temperature. In addition, other authors such as García-Tejero et al. reported the higher sensitivity of the canopy temperature for detecting water stress in citrus trees, in comparison with other physiological 
Figure 4.

Relationship between temperature variation $(\Delta T)$ and stem-water potential $\left(\Psi_{\text {Stem }}\right)$ for almond trees.

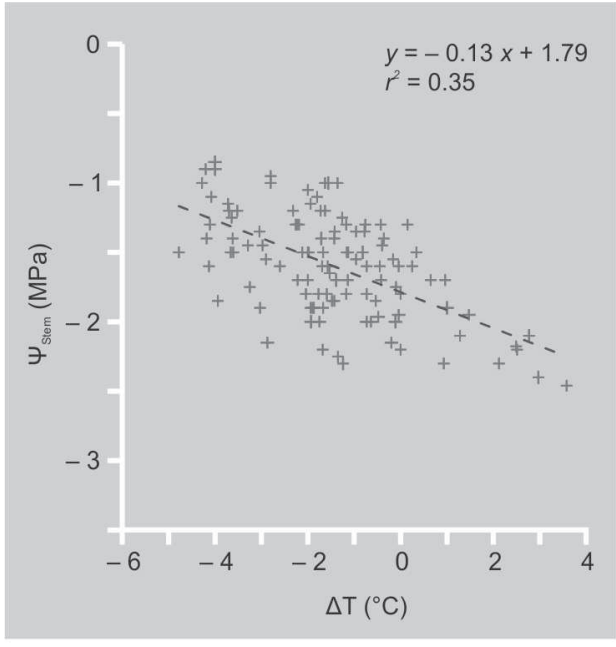

Figure 5.

Relationship between temperature variation $(\Delta T)$ and stomatal conductance $\left(\mathrm{g}_{\mathrm{S}}\right)$ for almond trees.

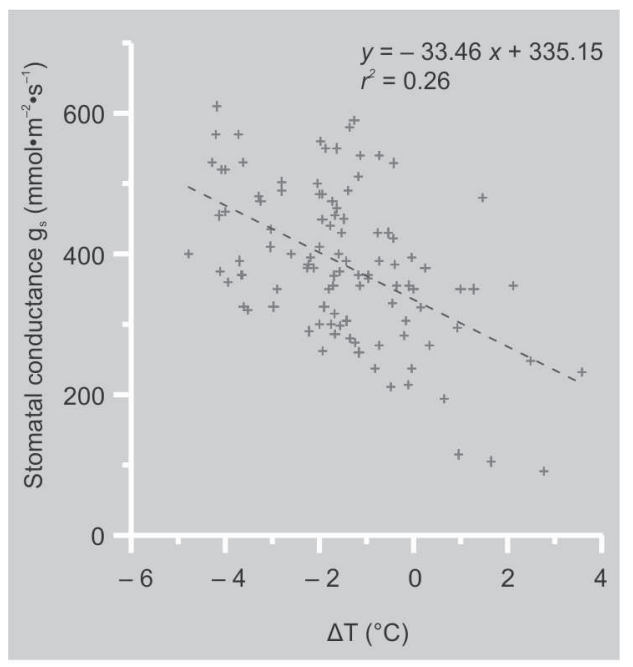

variables such as $\Psi_{\text {Stem }}$ or stomatal conductance [38].

\subsection{Relating thermal canopy temperature to other physiological parameters and model validation}

As a means of establishing the pattern of crop physiological response to water stress, the relationships among the parameters measured were studied. Significant relationships $(p<0.01)$ were found for $\Delta \mathrm{T}$ and $\Psi_{\text {Stem }}$ readings (figure $4, r^{2}=0.35$ ). It was found that, for $\Psi_{\text {Stem }}$ below $-1.8 \mathrm{MPa}$, the $\mathrm{T}_{\mathrm{C}}$ increased up to air temperature, reflecting that, below this value there is a significant decrease in the canopy cooling capacity through its transpiration; decreasing this significantly. Significant relationships between $\Delta \mathrm{T}$ and stomatal conductance were also found (figure $5, r^{2}=0.26$ ), although there was greater variability in comparison with $\Psi_{\text {stem. In this context, Jones et al. argued }}$ that the difficulty of relating the average temperature of multiple differently oriented surfaces to stomatal conductance of individual leaves would be highly related to the relative orientation of leaves with respect to the solar radiation [39]. The development stages of the canopy structure and the leaves also affect the temperature and how it varies with view angle. In consideration of these relationships, stomatal conductance values below $335 \mathrm{mmol} \cdot \mathrm{m}^{-2} \cdot \mathrm{s}^{-1}$ would promote increments in the differential of canopy-air temperature $(\Delta \mathrm{T})$ of up to $0^{\circ} \mathrm{C}$ (figure 5 ). That is, below this value the crop transpiration was being limited by a water shortage or worse weather conditions, and the canopy cooling capacity would be limited. Thus, decreased water uptake closes stomata, lowering transpiration and raising leaf temperatures [15, 16, 40].

Despite this, it is evident that other variables such as VPD (Vapor Pressure Deficit), $\mathrm{R}_{\mathrm{n}}$ (net radiation) or the timing measurement should be taken into account when an irrigation scheduling is developed, taking the $\Delta \mathrm{T}$ as priority information. According to Sepulcre-Cantó et al., similar relationships between $\Psi_{\text {Stem }}$ and $\mathrm{T}_{\mathrm{C}}$ for olive trees were reported, with $r^{2}$ varying between 0.25 and 0.62 [41], suggesting that $\Delta \mathrm{T}$ is a potential parameter for detecting water stress at the tree level. In addition, Wang and Gartung [23] pointed out the strong relationships $\left(r^{2}=0.70\right)$ between $\Delta \mathrm{T}$ and $\Psi_{\text {Stem }}$ in peach [Prunus persica (L.) Batsch] trees. Also, García-Tejero et al. showed in citrus trees highly significant relationships of $\Delta \mathrm{T} v s$. $\Psi_{\text {Stem }}\left(r^{2}=0.75\right)$ and stomatal conductance $\left(r^{2}=0.46\right)$ [39]. Consequently, these authors suggested the use of infrared canopy-temperature measurements as a promising method for assessing plant-water stress, especially in arid and semiarid climates under deficit-irrigation strategies on the plot scale. However, it must be taken into 
account that these relationships would be an approximation to the true values of $\Psi_{\text {Stem }}$ and stomatal conductance, and, hence, these would be a preliminary assessment of crop water stress.

Given these relationships, the software used could be modified. That is, this was able to provide not only the average values of the $\mathrm{T}_{\mathrm{C}}$ and hence the $\Delta \mathrm{T}$, but also an approach to $\Psi_{\text {Stem }}$ and stomatal conductance. This improves other known software that only allows time-consuming processing of thermal images and moreover does not indicate the crop-water status based on other physiological variables.

Thus, the program was modified in order to estimate the stomatal conductance and $\Psi_{\text {Stem }}$ by taking into account the $\mathrm{T}_{\mathrm{C}}$. A new query line was introduced to ask the user which values could be obtained for the air temperature $\left(\mathrm{T}_{\text {air }}\right)$. With the expected values (E) and the variance $\left(\sigma^{2}\right)$ for the temperature, the expected values and variance for stomatal conductance and $\Psi_{\text {Stem }}$ can be calculated as follows:

$$
\begin{aligned}
& \Delta T=T_{c}-T_{\text {air }} \\
& g_{s}=-32.02 \Delta T+261.09 \\
& \psi_{\text {stem }}=-0.16 \Delta T-1.82
\end{aligned}
$$

$\mu_{\Delta T}=E[\Delta T]=E\left[T_{c}-T_{\text {air }}\right]=E\left[T_{c}\right]-T_{\text {air }}$

$\sigma_{\Delta T}^{2}=E\left[\left(\Delta T-\mu_{\Delta T}\right)^{2}\right]=E\left[\left(T_{c}-T_{a i r}-\mu_{T}-T_{a i r}\right)^{2}\right]=\sigma_{T_{c}}^{2}$

$f(x)=a x+b \rightarrow$

$\mu_{f(x)}=E[f(x)]=E[a x+b]=a E[x]+b$

$\Rightarrow\left\{\begin{array}{c}\mu_{g_{s}}=-32.02\left(\mu_{T c}-T_{a i r}\right)+261.09 \\ \mu_{\varphi_{s e v e n}}=-0.16\left(\mu_{T c}-T_{a i r}\right)-1.82\end{array}\right.$

$\sigma_{f(x)}^{2}=E\left[f(x)-\mu_{f(x)}\right]=E\left[\left(a x+b-a \mu_{x}-b\right)^{2}\right]=a^{2} \sigma_{x}^{2}$

$\Rightarrow\left\{\begin{array}{c}\sigma_{g_{s}}^{2}=1025.2804 \sigma_{T}^{2} \\ \sigma_{\varphi_{s t r m}}=0.0256 \sigma_{T}^{2}\end{array}\right.$

where E represents the expected values; $\mathrm{T}_{\mathrm{C}}$, the canopy temperature; $\mathrm{T}_{\text {air }}$, the air temperature; $\mu$, the average; $g_{s}$, the stomatal conductance; $\Psi_{\text {Stem }}$, the stem-water potential at midday; and $\sigma^{2}$, the variance.

The approach was assessed considering the relationships from values measured for $\Psi_{\text {Stem }}$ and stomatal conductance vs. the values estimated from $\Delta \mathrm{T}$. The validation of the estimated values vs. those measured in the

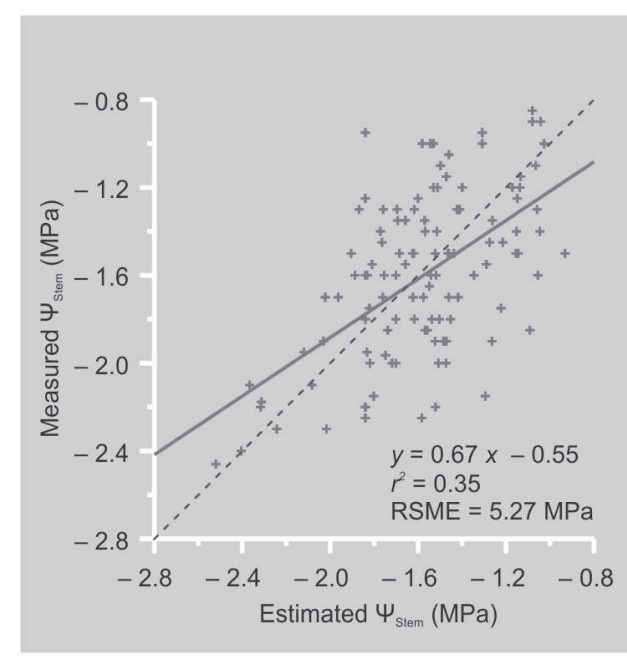

Figure 6.

Relationship between the estimated and the measured stem-water potential $\left(\Psi_{\text {Stem }}\right)$ for almond trees. The continuous line represents the linear relation between estimated and measured $\Psi_{\text {Stem }}$, whereas the dashed line shows a 1:1 relation between these variables.

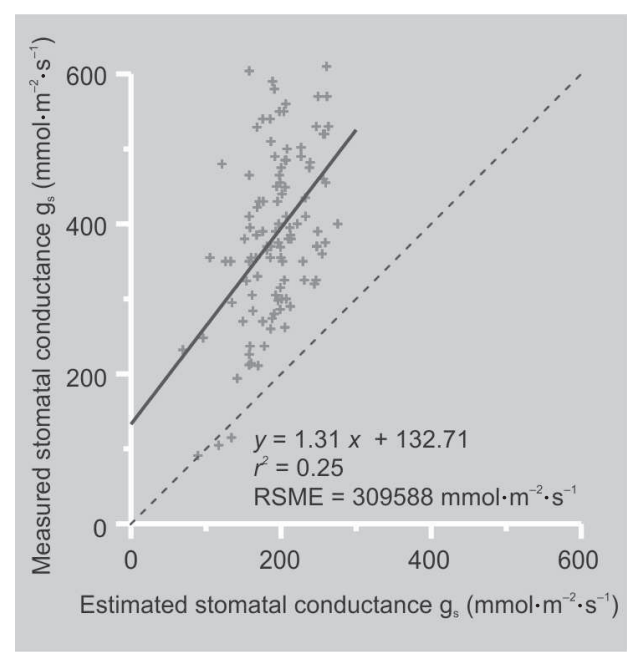

\section{Figure 7.}

Relationship between the estimated and the measured stomatal conductance $\left(g_{s}\right)$ for almond trees. The continuous line represents the linear relation between estimated and measured $\Psi_{\text {Stem }}$, whereas the dashed line shows a 1:1 relation between these variables. field for $\Psi_{\text {Stem }}$ shows that the estimates are close to the 1:1 line, with a slope of 0.67 (figure 6). However, when field values of $\Psi_{\text {Stem }}$ were below $1.6 \mathrm{MPa}$, the estimate proved to be a slight overestimation of this parameter.

In relation to the estimation of stomatal conductance, this was slightly worse than $\Psi_{\text {Stem }}$ (figure 7), values being underestimated for the entire range of measurements.

Similar findings have been reported by Jones et al. [21], Smith [42], and Testi et al. [43], among others, with especially remarkable relationships being calculated by Berni et al. in olive trees for mapping the canopy 
conductance on the plot scale using highresolution thermal-sensing imagery [20]. These authors reported highly significant relationships between measured and estimated stomatal conductance, with slopes ranging between 4.50 and 1.07, depending on the time of measurement.

Assuming these results, canopy temperature would be a profitable water stress index, especially for monitoring of large crop areas. The proposed method allows one to process the crop physiological status in relation to its water status quickly. However, although further work may be needed to improve the accuracy of estimating daily measurements when weather conditions are highly variable, the proposed technique constitutes a potential tool for precision drought-stress and irrigation scheduling.

\section{Conclusions}

Our work presents a methodological proposal for thermal-image analysis under water-stress conditions, which has been previously developed and evaluated in juvenile almond trees. The procedure developed constitutes a promising alternative for examining the crop-water status by selecting the real area from plant canopy images and avoiding masking with other materials.

In addition, according to our present results, the infrared measurement of canopy temperature can be used for estimating the $\Psi_{\text {stem }}$ and stomatal conductance parameters under water stress subjected to deficit-irrigation programmes, by improving our knowledge of plant-water relations.

\section{Acknowledgements}

The author I. García-Tejero received a contract co-financed by the European Social Fund Operational Programme (FSE) 20072013: "Andalucía is moving with Europe".

\section{References}

[1] Martin G.C., Kester D., Almond growth and development, in: Micke W.C., Kester D.
(Eds.), Almond orchard management, Div. Agric. Sci., Univ. Calif., Berkeley, U.S.A., 1978, pp. $46-51$.

[2] Girona J., Mata M., Marsal J., Regulated deficit irrigation during the kernel filling. Period and optimal irrigation rates in almond, Agric. Water Manag. 75 (2005) 152-167.

[3] Goldhamer D.A., Viveros M., Salinas M., Regulated deficit irrigation in almonds: effects of variations in applied water and stress timing on yield and yield components, Irrig. Sci. 24 (2006) 101-114.

[4] Nanos G.D., Kazantzis I., Kefalas P., Petrakis C., Stravroulakis G.G., Irrigation and harvest time affect almond kernel quality and composition, Sci. Hortic. 96 (2002) 246-256.

[5] Castel J.R., Fereres E., Responses of young almond trees to two drought periods in the field, J. Hortic. Sci. 57 (1982) 175-187.

[6] Marsal J., Girona J., Mata M., Leaf water relation parameters in almond compared to hazelnut trees during a deficit irrigation period, J. Am. Soc. Hortic. Sci. 122 (1997) 582-587.

[7] Romero O., Botia P., Garcia F., Effects of regulated deficit irrigation under subsurface drip irrigation conditions on vegetative development and yield of mature almond trees, Plant Soil 260 (2004) 169-181.

[8] Durán Z.V.H., Rodríguez C.R., Franco D., Impact of sustained-deficit irrigation on tree growth, mineral nutrition, fruit yield and quality of mango in Spain, Fruits 66 (2011) 257268.

[9] Johnson R.S., Handley D.F., Using water stress to control vegetative growth and productivity of temperate fruit trees, HortScience 35 (2000) 1048-1050.

[10] Intrigliolo D.S., Castel J.R., Evaluation of grapevine water status from trunk diameter variations, Irrig. Sci. 26 (2007) 49-59.

[11] García-Tejero I., Durán Z.V.H., Rodríguez P.C.R., Muriel F.J.L., Water and sustainable agriculture, Springer Briefs in Agriculture, Springer Science + Business Media, Neth., 2011.

[12] Mahhou A., De Jong T.M., Shackel K.S., Cao T., Water stress and crop load effects on yield and fruit quality of Elegant Lady peach [Prunus persica (L.) Batch], Fruits 61 (2011) 407-418.

[13] García-Tejero I., Durán Z.V.H., Muriel F.J.L., Jiménez B.J.A., Linking canopy temperature and trunk diameter fluctuations with other 
physiological water status tools for water stress management in citrus crops, Funct. Plant Biol. 38 (2011) 106-117.

[14] Jiménez-Bello M.A., Ballester C., Castel J.R., Intrigliolo D.S., Development and validation of an automatic thermal imaging process for assessing plant water status, Agric. Water Manag. 98 (2011) 1497-1504.

[15] Tubaileh A.S., Sammis T.W., Lugg D.G., Utilization of thermal infrared thermometry for detection water stress in spring barley, Agric. Water Manag. 12 (1986) 75-85.

[16] Blonquist J.M., Norman J.M., Bugbee B., Automated measurement of canopy stomatal conductance based on infrared temperature, Agric. Forest Meteorol. 149 (2009) 1931-1945.

[17] Erlher W.L., Cotton leaf temperatures as related to soil depletion and meteorological factors, Agron. J. 65 (1973) 404-409.

[18] Jackson R.D., Idso S.B., Reginato R.J., Pinter P.J., Canopy temperature as a crop water stress indicator, Water Resour. Res. 17 (1981) 1133-1138.

[19] García-Tejero I., Deficit irrigation for sustainable citrus cultivation in Guadalquivir river basin, Univ. Sevilla, Thesis, Sevilla, Spain, 285 p., 2010.

[20] Berni J.A.J., Zarco T.P.J., Sepulcro C.G., Fereres E., Villalobos F., Mapping canopy conductance and CWSI in olive orchards using high resolution thermal remote sensing imaginery, Remote Sens. Environ. 113 (2009) 2380-2388.

[21] Jones H.G., Stoll M., Santos T., de Sousa C., Chaves M.M., Grant O.M., Use of infrared thermography for monitoring stomatal closure in the field: application to grapevine, J. Exp. Bot. 53 (2002) 2249-2260.

[22] Zarco-Tejada P.J., Berni J.A.J., Suárez L., sepulcré-Cantó G., Morales F., Miller J.R., Imaging chlorophyll fluorescence with an airborne narrow-band multispectral camera for vegetation stress detection, Remote Sens. Environ. 113 (2009) 1262-1275.

[23] Wang D., Gartung J., Infrared canopy temperature of early-ripening peach trees under postharvest deficit irrigation, Agric. Water Manag. 97 (2010) 1787-1794.

[24] Wang X., Yang W., Wheaton A., Cooley N., Moran W., Automated canopy temperature estimation via infrared thermography: a first step towards automated plant water stress monitoring, Comput. Electron. Agric. 73 (2010) 74-83.
[25] Anon., World reference base for soil resources, Food Agric. Organ. U. N. (FAO), Rome, Italy, 1998.

[26] Anon., Carte bioclimatique de la zone méditerranéenne, UNESCO-FAO, Not. Explic., Paris, France, 1963.

[27] Doorenbos J., Pruitt W.O., Las necesidades de agua de los cultivos, FAO, ser. Riegos y Drenaje, tomo 24, Rome, Italy, 1977.

[28] Monteith J.L., Unsworth M.H., Principles of environmental physics, 3rd ed., Acad. Press, Amst., Neth., 2008.

[29] Scholander P.F., Hammel H.T., Hemmingsen E.A., Bradstreet E.D., Hydrostatic pressure and osmotic potential of leaves of mangrove and some other plants, Proc. Natl. Acad. Sci. U.S.A. 52 (1964) 119-125.

[30] Kernighan B.W., Ritchie D.M., The C Programming Language, 1st ed., Prentice Hall, Englewood Cliffs, N.J., U.S.A., 1978.

[31] Anon., Programming Languages-C, ISO/IEC 9899 WG 14, Int. Stand. Organ., 1999.

[32] Shackel K.A., Ahmadi H., Biasi W., Buchner R., Goldhamer D., Gurusinghe D., Hasey S., Kester D., Krueger B., Lampinen, B., McGourty G., Micke W., Mitchman E., Olson B., Pelletrau K., Philips H., Ramos D., Schwankl L., Sibbett S., Snyder R., Southwick S., Stevenson M., Thorpe M., Weinbuam S., Yeager J., Plant water status as an index of irrigation need in deciduous fruit trees, HortTechnology 7 (1997) 23-29.

[33] Goldhamer D.A., Fereres E., Irrigation scheduling of almond trees with trunk diameter sensors, Irrig. Sci. 23 (2004) 11-19.

[34] Nortes P., Respuesta Agronómica y Fisiológica del Almendro al Riego Deficitario. Indicadores de Estrés Hídrico, Univ. Politéc. Cartagena, Thesis, Spain, 2008, 194 p.

[35] Gomes-Laranjo J., Cutinho J.P., Galhano V., Cordeiro V., Responses of five almond cultivars to irrigation: Photosynthesis and leaf water potential, Agric. Water Manag. 83 (2006) 261-265.

[36] Chaves M.M., Pereira J.S., Maroco J., Rodrigues M.L., Ricardo C.P.P., Osório M.L., Carvalho I., Faria T., Pinheiro C., How plants cope with water stress in the field? Photosynthesis and growth, Ann. Bot. 89 (2002) 907916.

[37] Naor A., Irrigation scheduling and evaluation of tree water status in deciduous orchards, Hortic. Rev. (2006) 112-165. 
[38] García-Tejero I., Durán Z.V.H., Jiménez B.J.A., Muriel F.J.L., Improved water-use efficiency by deficit-irrigation programmes: Implications for saving water in citrus orchards, Sci. Hortic. 128 (2011) 274-282.

[39] Jones H.G., Serraj R., Loveys B.R., Xiong L., Wheaton A., Price A.H., Thermal infrared imaging of crop canopies for the remote diagnosis and quantification of plant responses to water stress in the field, Funct. Plant Biol. 36 (2009) 978-989.

[40] Jurema R., Nogueira M.C., Ibrahim M.A., Bandeira A.M., Stomatic behaviour and leaf water potential in young plants of Annona squamosa submitted to saline water stress, Fruits 59 (2004) 209-214.

[41] Sepulcre C.G., Zarco T.P.J., Jiménez M.J.C., Sobrino J.A., de Miguel E., Villalobos F.J., Detection of water stress in an olive orchard with thermal remote sensing imagery, Agric. Forest Meteorol. 136 (2006) 31-44.

[42] Smith R.C.G., Inferring stomatal resistance of sparse crops from infrared measurements of foliage temperature, Agric. Forest Meteorol. 42 (1988) 183-198.

[43] Testi L., Orgaz F., Villalobos F.J., Variations in bulk canopy conductance of an irrigated olive (Olea europea L.) orchard, Environ. Exp. Bot. 55 (2006) 15-28.

\section{Aproximación a la evaluación de imágenes térmicas por infrarrojos en almendros bajo condiciones de estrés hídrico.}

Resumen - Introducción. La optimización del uso del agua en la agricultura implica la combinación de técnicas fisiológicas, tecnológicas y de ingeniería, especialmente aquellas que permiten establecer un seguimiento en continuo del estado hídrico de plantas sometidas a riego deficitario. La metodología para estimar el estrés hídrico mediante el análisis de imágenes térmicas fue desarrollada a partir del seguimiento del estado fisiológico de un cultivo de almendros jóvenes bajo condiciones de aportes limitados de agua. Material y métodos. Se definieron dos tratamientos de riego durante el período de máxima demanda evapotranspirativa (214-243 día del año), en una parcela experimental de almendros [Prunus dulcis (Mill.) DA Webb., cv. Guara]: un tratamiento de riego deficitario de baja frecuencia (RDBF), que recibió dotaciones hídricas en función del estado hídrico del cultivo; y un tratamiento control $\left(\mathrm{C}_{100}\right)$ que recibió el 100\% de la demanda evapotranspirativa. Se realizaron medidas periódicas de la temperatura de la cubierta vegetal (Tc) mediante una cámara de infrarrojos, junto con otras medidas tradicionalmente más usadas como son el potencial hídrico del tallo $\left(\Psi_{\text {Stem }}\right)$ y la conductancia estomática $\left(\mathrm{g}_{\mathrm{s}}\right)$. Se analizó la evolución temporal de los parámetros establecidos, así como las relaciones existentes entre ellos. Resultados y discusión. Se encontraron correlaciones altamente significativas en la evolución temporal de los parámetros estudiados. Por otra parte, la metodología empleada para al análisis y procesamiento de las imágenes térmicas permitió un ahorro importante de tiempo, ofreciéndonos además la posibilidad de realizar estimaciones significativas del potencial hídrico y la conductancia estomática. Conclusión. Los resultados obtenidos confirman que la termografía de infrarrojos es una técnica adecuada para evaluar el estado hídrico de los cultivos, y puede suponer un importante avance en la automatización del seguimiento del mismo en el cultivo de almendros.

España / Prunus dulcis / cubierta de copas / temperatura / termografía infrarroja / necesidades de agua / déficit de humedad en el suelo 